\author{
Теодора Д. Бојовић \\ Међународни центар за православне студије, Ниш \\ Завод за вредновање квалитета образовања и васпитања, Београд \\ e-mail: tbojovic@ceo.gov.rs
}

\title{
ДОМЕНТИЈАНОВА ПОЕТИКА ВИСИНА У ИНТЕРТЕКСТУАЛНОМ КЉУЧУ
}

Апстракт: У раду је, најпре, пружена генеза савремених интертекстуалних поставки, у циљу препознавања основних карактеристика поменуте теорије у делима старе српске књижевности. С обзиром на то да су тежња ка угледању на ауторитативне текстове, међутекстовност и преплитање дискурса у низу главних поетичких одлика старе книжевности, гледишта интертекстуалности налазе широку примену у анализи дела. Мотиви узвишеног у Доментијановим песничким наративима Житија Светог Саве творе поетику висина. Поетика висина ослања се, такође, на феномен достизања Царства небеског, обожења и откривања Логоса. У интертекстуалном кључу, анализирају се поменути мотиви кроз различите тематске аспекте и идентификују се основни извори интертекста. Напослетку, уочено је да мотиви који творе поетику висина креирају особени конщепт хронотопа, те да се кроз поетику висина укритају поетика простора и поетика времена.

Кључне речи: Доментијан, Житије Светог Саве, поетика висина, интертекстуалност, интертекст

\section{L'intertextualite, од идеје до дефиниције}

Наговештај значаја интертекстуалности пионирски је пласирао Михаил Бахтин ${ }^{1}$, афирмишући идеју о „међуповезаности текстова”, у оквиру које посматра текст као систем значења у дијалошкој узајамности, који „одражава све текстове (у границама) дате мисаоне cфере"'. Сам појам l'intertextualite креира Јулија Кристева (1967) у студији Le mot, le dialogue et le roman, док у каснијим анализама књижевни текст дефинише на следећи начин: „он је писање - реплика (функција или негација) неког другог (неких других текстова)”3. Такође, у есеју Бахтин, реч, дијалог и роман, Кристева наводи: „Сваки текст се гради као мозаик цитата, сваки текст је апсорпција и трансформација другог текста"4. Значајан допринос у настајању и развоју како појма, тако и теорије интертекстуалности приписује се Ролану Жерару Барту, чија су виђења допринела распрострањености појма широм европских кругова. Барт је пажњу усмерио на односе текста и читаоца, сматрајући да су они пресудни за проучавање интертекстуалних веза. Суштина теоријских ставова Ролана Барта налази се у концепту плуралности текста, тј. принципа да се сваком тексту може приписати

1 Такође, међу најстаријим сазнањима о интертекстуалности треба напоменути да је и Виктор Шкловски двадесетих година 20. века писао о терминима „цитатне мотивације”, „цитатног поступка” и „цитатне теме” (Шеатовић Димитријевић 2004, 11).

2 Бахтин 1995, 12.

3 Кристева 1969, 120.

4 Према Јуван 2013, 11. 
безброј значења. Истраживања доајена интертекстуалних поставки представљала су изазов и подстрек за даља текстолошка проучавања, те су различита имена ауторитативних научника пружала различиту дефиницију и погледе на интертекстуалност. Концизну, а прилично обухватну генезу дао је Душан Живковић у раду Појам интертекстуалности (2010), у коме, поред поменутих имена, наводи и схватања Мишела Рифатера (који надограђује Бартове поставке и још више наглашава улогу рецепције); Хајнриха Плета који „сугерише да се одређени текст не може интерпретирати изоловано, јер је он увек посттекст, као и пре-текст, те да овакву дистинкцију можемо тумачити као вођење дијалога са традицијом, и као потенцијални подстрек стварању нових текстова"5; Живковић, такође, анализира гледишта Николаса Цурбурга, Урлиха Бројха и др. ${ }^{6}$

Порекло речи интертекстуалност налази се у корену латинске речи intertexere (уткивати, уплетати), а сама реч intertextualite означава преплитање и повезаност. Интертекст је, поједностављено речено, међутекст и међузависност две компоненте односа. Подробније теоријско дефинисање појма се од његовог настанка до савремених истраживања мењало. У области науке о књижевности, теоретичари су, најпре, направили дистинкцију између имплицитне и експлицитне интертекстуалности, док се овим појмовима прикључују и термини опште и посебне. Детаљни преглед поменутих нивоа представљен је у књизи Интертекстуалност Марка Јувана. Општа интертекстуалност схваћена је као својство свих текстова ${ }^{7}$, док је имплицитна нужна карактеристика свих књижевних дела. Експлицитни вид интертекстуалности каткад се поистовећује са цитатним поступком, који се посебно развио у постмодернизму, те се надаље формирала и посебна теорија цитатности, односно - цитатологија.

Најједноставније речено, интертекстуалност се може схватити у ширем смислу - сваки текст представља интертекст сам по себи; и у ужем, који подразумева дијалог са читаоцем који препознаје дијалог са традицијом. Ужа интертекстуалост подразумева прецизирање експлицитног или имплицитног упућивања на други текст. Живковић у својој студији поменуто дефинише на следећи начин: „Треба разликовати експлицитну интертекстуалност као аутопоетички поступак, где ауторским интенцијама текст постаје интертекст у употреби различитих алузија, парафраза или цитата, од имплицитне интертекстуалности, која сеже до ауторовог несвесног дијалога са књижевном традицијом"8. Када је реч о интертекстуалним врстама и формама, односно фигурама, оне су дефинисане и пре самог настанка појма интертекстуалности. Најзначајније су топос (опште место) $)^{9}$, цитати ${ }^{10}$, алузија $^{11}$ и парафраза ${ }^{12}$ (имитација, превод).

5 Живковић 2010, 271.

6 Више у: Појам интертекстуалности, Душан Живковић, 2010.

7 Општа интертекстуалност није привилегија књижевности, она је услов за креацију текстова. „Сваки текст настаје, постоји и схваћен је тек преко садржинских и формалних веза с другим изјавама, постојећим текстовима, али такође и са знаковним системима (кодовима), типовима дискурса, језичким врстама, стилским и жанровским конвенцијама, претпоставкама, стереотипима, општим местима, архетиповима или клишеима" (Јуван 2013, 51, 52).

$82010,285$.

9 Трезор мисаоних крилатица, цитата, композиционих, мотивских или стилских клишеа, архетипских ликова, слика или ситуација, који су се у књижевности средњег века до 18. века понављали у бројним варијантама (Јуван 2013, 24).

10 Навод, репродукција, позајмљивање одломка из другог текста.

11 Алузија је у књижевности и изван ње устаљен, али теже схватљив начин интертекстуалног реферирања, јер је реч о форми посредног говора. (...) Приликом алудирања скривени садржај говорног сегмента остаје прећутан, није непосредно именован или описан, иако у тексту неки израз или структурни узорак на њега упућује, сугеришући денотацију и конотацију (Јуван 2013, 30).

12 Обнова нечега познатог, обично класичног текста у стиху или прози, при чему се његов изворни смисао мора очувати, испричан другим речима (Исто, 32). 
На крају, разумевање како појма тако и теорије интертекстуалности и њених фигура сложено је и изискује схватање свих досадашњих дефиниција, остављајући простора за будуће.

\section{2. Нова теорија о старој појави}

Теорије 20. века значајне су за књижевнонаучно дефинисање старих појава. Поступци интертекстуалности нису карактеристика дела савременијих писаца, већ се тежња ка угледању на друге текстове, међутекстовност и преплитање текстова уочава и у остварењима најстаријих књижевности. Дубравка Ораић Толић интертекстуалност сагледава као и Павао Павличић - она јесте појава која је стара колико и култура. Књижевни текстови одувек су (а и даље) настају под утицајем других текстова: „Књижевни текст ступа у однос с другим текстовима већ због тога што припада књижевности, али и обратно: он припада књижевности зато што успоставља везе с другим текстовима"13. Још од старог века па надаље, у песничким и непесничким врстама писмености и књижевности, било је веома раширено уплитање текстова у текстове, а њихова значењска, вредносна, формална и жанровска међузависност, односно интеракција, појављивали су се на различите начине ${ }^{14}$.

Питање интертекстуалности, означено управо тим појмом, теоријски је актуелизовано тек у 20. веку, међутим, о поступцима међутекстовног повезивања и ослањања на друге текстове, међу проучаваоцима средњовековне књижевности, одавно је писано. Разлог лежи у свеприсутности директног и индиректног упућивања на друге текстове, те је тако интертекстуалност у низу главних поетичких одлика српске средњовековне књижевности. У старим текстовима, индикативи који упућују на појаве које се могу означити као интертекстуалне везе су разнолики. Зоран Карановић ${ }^{15}$ индикативе дефинише као места која у тексту на ма који начин указују на његову повезаност са другим текстовима, а они су, у делима средњовековних писаца, у најширем смислу, најпре на нивоу дијалога са наслеђем. У свету старе српске књижевности, религиозно наслеђе преузимано је на више нивоа: фабулативни и тематско-мотивски слој, општа места, лексички слој (устаљени изрази) итд. Читав наратив подређен је религиозном дискурсу (библијском, светоотачком и богослужбеном, односно литургијском). Дакле, веза између средњовековног текста и ризнице наслеђа читаоцу пружа мноштво изазова у уочавању међутекстовних веза. Вишедеценијска посвећеност проблемима и питањима старе књижевности професора Александра Наумова и професора Драгише Бојовића изнедрила је бројне радове посвећене управо проблему интертекстуалности: већина радова удружена је у књигама Старо и ново Александра Наумова $^{16}$ и Српска књижевност и свето предање Драгише Бојовића ${ }^{17}$.

Још је пољски слависта, Александар Наумов, анализирајући Житије Св. Саве Теодосија Хиландарца ${ }^{18}$, пружио теоријска начела узорних текстова на која су се ослањали средњовековни писци. Те тако, Свето писмо дефинише као „идеолошки оквир и главну ризницу мисли и стилских средстава средњовековне књижевности, посебно

13 Шеатовић Димитријевић 2004, 24.

14 Јуван 2013, 15.

$152002,9$.

16 Наумов 2009. Веома значајне резултате о проблему интертекстуалности у средњовековном књижевном тексту остварили су и Рикардо Пикио и Марчело Гардзанити. Видети: Пикио, 1993; Гардзанити 17 Бојовић 2019.

18 О библијским местима у Житију Света Петра Коришког писала је Ирена Шпадијер, 1997. 
хагиографије"19. Наумов посебну пажњу посвећује принципу који је типичан за средњи век, а то је потрага за константном корелацијом описиваног предмета или догађаја са већ постојећим моделом. Управо се у идеји посредничког слоја, коју је утемљио овај пољски слависта, налази велики део објашњења функционисања поетике стварања средњовековног аутора: „Као и цела култура, књижевни систем је био хијерархијски организован према категеоријама светости аутора дела и сакралности описиваног предмета, а такође према начину повезивања са посредничким слојем и са идејом из идеолошког слоја, која одговара појединим сликама.

Прелажење са идеје на конкретно дело, како знамо, има три етапе:

1. дата идеја налази одраз на нивоу апстрактних, инваријантних слика из посредничког слоја према захтевима етикеције;

2. апстрактне слике из посредничког слоја се конкретизују кроз избор варијанти на нивоу конкретних уметничких потреба

3. слика, чије је постојање у одређеном књижевном делу запис апстрактног посредничког слоја, у стваралачкој свести кодирана је као конкретна топичка шема или као језичко-стислки облик писмено утврђеног узорног исказа, памћен са одређеном тачношћу."20

Неопходно је средњовековне текстове тумачити у духу времена коме припадају, имајући у виду контекст настајања књижевног дела. Текст мора бити тумачен у зависности од културног кода, а шире посматрано, мора се имати у виду његов дијалог са целокупним „универзумом” уметничке традиције $\mathrm{e}^{21}$. Културни код средњовековног текста јесте богослужбени код, док ослањање на наслеђе представља наставак религиозног наратива. Поетика византијске, а тиме и средњовековне књижевности у служби је исказивања или откривања Логоса ${ }^{22}$, па се, самим тим, текстови ослањају на теолошки канон. Бојовић истиче да постоје „три доминантна рецепциона нивоа којима се успоставља комуникација са литерарном традицијом. То дело је, у ствари, одраз утицаја тројне литерарне светости - trinea litterariae sancitates, коју чине Свето писмо (Стари и Нови завет), Света Литургија (богослужбене песме) и Свети Оци (патристички текстови)"'23. Дакле, поменути текстови тројне литерарне светости јесу ауторитативни текстови средњовековном аутору и јесу подтекст новонасталог дела. Александра Костић Тмушић истиче да „сва наша житија, од Светог Саве до Пајсија Јањевца, представљају сложену грађу састављену од наративних пасажа, мноштва библијских цитата, реторских и песничких делова" 24 .

У области старе књижевности, највише су разматрани утицаји Светог писма, као доминантног модела и узора средњовековном аутору, међутим, истражен је и изузетни патристички утицај. О рецепцији књижевности светих отаца писао је Бојовић, истичући да у популарна дела хришћанске књижевности спадају и светоотачки списи. „Неки од текстова Светих отаца, нарочито песнички, саставни су део богослужења, док други имају хомилички или поучни карактер, па, такође, лако долазе до читалаца. Огроман корпус светоотачког наслеђа на различите начине долазио је до српских читалаца, најчешће преко превода, али и у изворном облику"25. Бојовић пише и о врстама интертекста, те

19 Наумов 2009, 84 .

20 Исто $2009,87$.

21 Живковић 2010, 268.

22 Види: Богдановић 1991, 61.

23 Бојовић 2009, 39.

$242017,50$.

25 Бојовић 2015, 25. 
наглашава да средњовековни аутор из ауторитативних текстова не црпи само идеје, већ се често служи и позајмицама у виду дословних цитата или парафраза. Уопште узев, поменуте врсте јесу и најфреквентније у делима старе српске књижевности.

Студија која анализира житије у интертекстуалном контексту, позивајући се на теоријско дефинисање ове појаве из 20. века, јесте рад Савино Житије Светог Симеона и интертекстуалност, аутора Маје Анђелковић. Коментаришући изворе коришћене за писање, поред књига trinea litterariae sancitates, Анђелковић наводи и правни текст, док међу врсте интертекста као најчешће издваја цитат, парафразу (укључујући преузимање модела библијског наратива), паралеле (атрибуирање и преузимање модела библијског наратива) и алузију ${ }^{26}$. Значајан допринос у теоријским поставкама теорије интертекстуалности као главне поетичке одлике средњовековне књижевности пружа рад исте ауторке Интертекстуалне везе Савиног Житија Светог Симеона и I и II Хиландарске повеље. Узимајући у обзир да се средњовековна књижевност ствара у црквеном дискурсу, Анђелковић закључује да ,аутору средњовековне књижевности цитатност није могућност него нужност". 27

Како је већ примећено, у средњовековном тексту уочавање врсте интертекста није нимало једноставно, нарочито када је реч о разликовању цитата и парафразе. Поменуто се објашњава чињеницом да су ауторитативни текстови били део литургијског и црквеног живота, па су аутори неретко цитате у дело инкорпорирали напамет. У том контексту, Наумов управо истиче да цитате из Светог Писма треба посматрати кроз призму богослужбене праксе, а не изоловано. „Скоро сви се интуитивно слажемо да су у већини случајева текстови били цитирани напамет и да су аутори памтили тај облик који су изговарали, односно слушали за време богослужења" 28 . Зато своје место у новом тексту нађу и позајмице из богослужбене поезије, из требника, октоиха, служабника и других књига.

На основу реченог, закључује се да теорија интертекстуалности, и даље прилично заступљена у савременим испитивањима, широку примену може наћи у текстовима наших средњовековних писаца. Идентификовање, најпре, извора интертекста представља велики изазов проучаваоцима старе књижевности.

\section{3. Доментијанова поетика висина у интертекстуалном кључу 29}

Савремени читалац и књижевни проучавалац, уронивши у мисаоно богатство бескрајно симболичних нити и изобиље међутекстовних веза које нуди средњовековни текст, сусреће се са питањем не тако једноставног одговора: Шта је читао средњовековни аутор? У контексту проблема међутекстовних релација, одговор, најпре, отвара могућности дешифровања извора интертекста. „Књижевни материјал који постоји пре стварања новог дела намеће се писцу према његовом знању - дару речи" 30 . Дар речи јеромонаха Доментијана изнедрио је дела засебног поетичког значења, која хагиографску књижевност допуњују посебним доментијанским сензибилитетом и особеним књижевним изразом. Са друге стране, списак литературе коју је Доментијан одлично познавао придаје његовим делима ерудитни карактер. Не само што иновира житијну форму, писац

262019,340 .

272020,230

$282009,26,27$.

29 Неким елементима интертекстуалности у Доментијановом делу бавили су се и: Љиљана Јухас Георгиевска (2001), Александра Костић Тмушић (2017) и Сара Немат (2020).

30 Наумов 2015, 88 . 
читаоцу предочава невероватну вештину у развијању наратива, у коме се препознају изузетне стилске конструкције.

Списак Доментијанове обавезне лектире одавно је саставио Ђорђе Трифуновић у раду „Доментијан песник светлости”31. Будући да је Доментијан неко време боравио у Кареји, на основу Карејског типика може се утврдити шта је читао. Свакодневно се служио Псалтиром, читао Четворојеванђеље и песме хришћанских песника. Трифуновић истиче да се из Старог завета наслађивао небеском фантастиком и апокалиптичним прозрењем, док је највећи утисак из Новог завета на њега оставио свет симбола и парабола еванђелисте Матеја, али цитира и Јована, Луку и Марка. Међу беседницима га је највише привукла сликовитост казивања апостола Павла. ${ }^{32}$ Претпоставља се да је на његово дело утицао и Шестоднев Јована Егзарха. ${ }^{33}$ Овоме треба додати и утицај писаца патристичке књижевности: Јефрема Сирина ${ }^{34}$, Јована Залатоуста ${ }^{35}$, Григорија Ниског, Григорија Богослова ${ }^{36}$ и других.

Уопште узев, Псалми Давидови заузимају посебно место када је реч о текстолошким узорима који се на различите начине инкорпорирају у текст оба Доментијанова житија. Псалми се у његовим делима препознају од идејне замисли, па до дословних цитата. У књизи Естетика Доментијанових житија, аутора Милорада М. Лазића, посебно се испитује утицај Псалтира. „Применом општих места из Псалтира, појачавају се књижевна поетичка и теолошка структурна вредност житија, али и естетичка. То важи за средњовековна дела уопште. Кроз поетику и естетику теоцентричне јеврејске поезије Давидових псалама Доментијан универзализује провенијенцију српске књижевности и њених естетичких вредности" 37 .

Свестраност Доментијановог погледа и богатства мисли огледа се у изобиљу различитих симбола присутних у његовим делима. „Тражећи симболе, Доментијан не гледа много у природу око себе. Загледан је више у небеса књижевности са којих је скинуо распрхнуте звезде" 38 . Стога, најфреквентнији мотиви у Доментијановим житијима јесу мотиви апстрактног, недодирљивог и узвишеног: светлости, небеса, звезда, сунца... Поводом изузетно развијене естетике светлости са правом ће се поред Доментијановог имена усталити синтагма из поменутог Трифуновићевог рада - песник светлости. У контексту утицаја ауторитативних текстова, када је реч естетици светлости, Бојовић примећује да је Доментијан изграђује на богатом патристичком наслеђу, на челу са

31 Трифуновић 1972.

32 Утицај Светог апостола Павла нагласили су Светозар Радојчић и Драгиша Бојовић.

33 „Јован Егзарх је на основама библијског описа стварања света за шест дана уз помоћ дела Василија Великог, Јована Златоустог, Северијана Гавалског, Аристотела и других саставио енциклопедију козмогоније, небеса, светлости и таме, земље и мора, биља и животиња, и човека" (Трифуновић 1972, 355).

34 Види: Драгиша Бојовић, „Доментијанова теологија љубави”, Трпеза премудрости, Београд: Рашка школа, Ниш: Центар за црквене студије, 85-107 и Драгиша Бојовић, Доментијанове позајмице о љубави", Прилози за књижевност, језик, историју и фолклор, књ. LXX, 139-142.

35 Види: Драгиша Бојовић, „Доментијан и Свети Јован Златоусти: симболика сунца”, Српска книжевност и свето предање, 2019.

36 Види: Станислав Хафнер, „Доментијан и Слово о закону и благодети митрополита кијевског Илариона”, Српски средюи век, прев. Јованка Калић, Слободан Грубачић, Београд: ЗУНС, Вукова задужбина, Нови Сад: МС, 2001.

37 1997, 182.

38 Трифуновић 1972, 359. 
утицајем (Псеудо) Дионисија Ареопагита: тај утицај најизраженији је преко симбола сунца и зрака ${ }^{39}$.

Житије Светога Саве у себи крије богатство мотива, симбола, метафоричких значења и алузија, те захтева константно враћање на текст зарад макар делимичног очитавања међутекстовне разуђености и ерудиције Доментијана, која је резултат свих поменутих утицаја. Са једне стране, комплексност очитавања свих могућих значења која дело крије налази се у доминантној одлици поетике средњовековне књижевности симболизму. „Поређења и метафоре добијају нову димензију: то сада нису само реторске фигуре него облик у којем се манифестује и препознаје духовна истина Бића" 40 . Са друге стране, чини се да фигуре, којима се Доментијан учестало служи, очитавањем откривају још шири распон духовних, трансцедентних, метафизичких схватања. Поред тога, понирање у све експлицитне и скривене ауторове интенције мора се вршити, имајући у виду, како Бојовић истиче, и само поетику жанра, али и ауторову теологију: „Када је реч о Доментијановом Житију Светог Саве оно се, нема сумње, не може сагледавати само у светлости поетике жанра, нити само у оквиру ауторове теологије. Доментијанова доктрина се не може свести на једну или другу димензију дела, већ подразумева читав спектар ауторских интенција и сложени систем порука, укључујући и заснивање националних и еклисиолошких идеја" ${ }^{\prime 1}$.

Од изобиља мотива који се експлицитно, али неретко и скривено, захтевајући посебан сензибилитет самог тумача, очитавају у поменутом Житију, у раду ћемо се задржати на онима који творе поетику најузвишенијег: поетику висина. Будући да је Доментијан већ означен као „песник узлета, свемира и свешира" 42 , неупитно је да су мотиви узвишеног свеприсутни у његовим песничким наративима. Од земље, у светлу поетике средњовековне књижевности, не може се тежити нигде друге - но до висина. Откривање Логоса подразумева ниво трансцедентне тежње ка достизању небеског и наднебеског. Дакле, најједноставније речено - на феномен достизања Царства небеског, обожења, али и на откривање Свевишњег, ослања се поетика висина у Житију Светога Саве. Управо у корену саме речи Свевишњи уочавамо висине, на чију се суштину ослањају мотиви у поменутом Житију, који природно настављају и допуњују низ његове недодирљиве, узвишене и метафизичке лексике.

Интертекстуалност се, у овом случају, огледа у идејном, мисаоном и лексичком ослањању на ауторитативне текстове. Тачније, интертекстуалност, у феномену поетике висина, свој одраз налази у идеји посредничког слоја, коју је дефинисао, као што смо већ истакли - А. Наумов. Апстрактна схватања висина, у библијском (псаламском) контексту, мотивски се инкорпорирају у лирским и надахнутим исказима јеромонаха Доментијана. Основни извор интертекста јесу, на првом месту, Псалми Давидови, док се уочавају и утицаји других књига Светог писма.

Мотиви узвишеног најзаступљенији су у Псалтиру. Псалми Давидови антологија су поетског слављења Бога у текстовима најузвишеније религиозне поезије. Истанчана и жива религиозна осећања, мноштво мотива и изузетних метафора присутни су у сабраним химнама Господу, које су са разлогом биле велика инспирација и надахнуће средњовековном аутору, нарочито Доментијану. Како Лазић примећује, Доментијан преузима „етос размишљања ове старозаветне књиге”43, те заиста можемо рећи - када је о висинама

$392009,206$.

40 Богдановић 1991, 64.

41 Бојовић 2019, 593.

42 Трифуновић $1972,358$.

43 1997, 182. 
реч - Доментијан преузима, најпре, суштину схватања овог симбола, који је на изузетан начин искоришћен у песничким налетима псалмопојца. Стихови, научени напамет, представљали су особен учинак у богонадахнутим хагиорафским сведочењима. ${ }^{44}$ Самим тим, у мноштву мотива нашли су се и они сабрани око поетике узвишеног - поетике висина.

У садејству и прожимању псаламских стихова и Доментијанових поетских наратива за ову прилику, у наставку рада, издвајамо само део могућих (и репрезентативних) мотива који, као што смо истакли, творе поетику висина. Мотиви су садржани у следећим тематским аспектима:

1) Господ на висинама

2) Силазак на земљу (са висина)

3) Милост и дела Божија

4) Глорификација висина наспрам овоземаљског

\section{Господ на висинама}

Као што смо истакли, наратив житија у служби је пута обожења и откривања Логоса, а најфреквентнији простор уз који се име Господње у Житију Светог Саве помиње јесу небеса и висине = небеска висина. Дакле, Он живи и пребива на висинама;

\begin{tabular}{|l|l|}
\hline Пс. 112, 5, 6 / Пс. 101, 20. & Житије Светог Саве $(58,61,130$. стр.): \\
\hline $\begin{array}{l}\text { Ко је као Господ, Бог наш, који обитава } \\
\text { на висинама и на смирене погледа; }\end{array}$ & $\begin{array}{l}\text { Онај који живи у висинама и на смирене } \\
\text { погледа, Бог отаца наших (...); } \\
\begin{array}{l}\text { Јер приниче са Висине свете Своје, } \\
\text { Господ са Неба на земљу погледа; }\end{array}\end{array}$ \\
$\begin{array}{l}\text { Преосвећени слави оца небеског који } \\
\text { седи на висинама и на смерне погледа } \\
(\ldots) ;\end{array}$ \\
$\begin{array}{l}\text { Ти сад свевидећим оком Твојим, и овде } \\
\text { погледај са висине своје безмерне; }\end{array}$ \\
\hline
\end{tabular}

Небеса и висине у старозаветној књизи припадају Њему и њима царује: „Јер су у руци Његовој крајеви земље, и висине гора Његове су” (Пс. 94, 4), Господ је на Небу припремио престо Свој, и Царство Његово влада над свима" (Пс, 102, 19). Са друге стране, јеромонах Доментијан Га, такође, неретко у Житију назива Оцем и Царем небеским: „и пружи своје преосвећене руке ка небеској висини, као Ономе који влада небом (подвукла Т.Б.) и земљом" (83. стр.)

Природно да поетику висина можемо да доведемо у везу са естетиком Царства Божијег, као универзалног појма. Висине су део космолошког аспекта Доментијанових мотива, а Царство Божије је, такође, у средњовековној књижевности у равни космолошког и есхатолошког. Поред Царства, слава је Господа на висинама и том

44 Псалтир је од свих библијских књига највише утицао на стил српских, као и осталих словенских писаца. Приручна књига монаха и лаика, научен напамет, псалтир са својим стиховим, фигурама и својим расположењима уградио у стару српску књижевност као њен праобраз и најомиљенији узор. Богдановић 1991, 129. 
простору Доментијанови јунаци теже: „да у висинама тражиш славу небеску и живот преподобних и праведних (2001: 39);

\begin{tabular}{|l|l|}
\hline Јеванђеље по Луки, 2, 14: & Житије Светог Саве (93. стр.): \\
\hline $\begin{array}{l}\text { Слава на висини Богу, и на земљи мир, } \\
\text { међу људима добра воља. }\end{array}$ & $\begin{array}{l}\text { (...) и где се слава у висинама } \\
\text { преузносаше, и на земљи мир обнављаше } \\
\text { се међу људима (...) }\end{array}$ \\
\hline
\end{tabular}

\section{Мотив силаска на земљу (са висина)}

Будући да се у Житију тежи библијским и духовним значењима, у низу мотива који оснажују присуство Логоса, ради непоколебиве (и ојачане) јунакове вере, налази се и мотив силаска на земљу:

Јован, 6, 38

„Јер сам сишао с неба не да творим вољу своју, него вољу Оца, који ме посла.”

\begin{tabular}{|l|l|}
\hline Пс. 143, 5. & Житије Светог Саве (66): \\
\hline Господе, приклони Небеса и сиђи & $\begin{array}{l}\text { (..) онога који је преклонио безмерну } \\
\text { висину и сишао на земљу ради нашег } \\
\text { спасења }\end{array}$ \\
\hline
\end{tabular}

У делу о напуштању Стефана Немање државе своје и примању анђелског образа, Доментијан такође пише: „Господ начелник слава, који је с висине посетио наш род и послао Духа Светога и сина свога јединороднога (...)”

„Молим вас, дакле, браћо, прво разумејте Божји милосрдан к нама долазак и Христово смирење, који је ради нашега спасења оставио безмерну висину и сишао с небеса (...)”

\section{Милост и дела Божја}

У Псалмима Давидовим милост, истина и велика дела Божја сежу до висина и небеса: „Јер се узвелича до Небеса милост Твоја, и до облака истина Твоја” (Пс. 56, 11), „Боже, до највиших висина величине што си учинио! Боже, ко је сличан теби?” (Пс, 70, 19), те тако и у молитвама у Житију, Сава се обраћа управо висинама „уздижући преподобне руке своје ка Вишњему” и „узвевши очи своје на небеску висину”.

Надаље се у истој молитви Доментијан, такође, позива на Псалтир:

\begin{tabular}{|l|l|}
\hline Пс. 109, 2. & Житије Светог Саве $(58,59):$ \\
$\begin{array}{l}\text { Жезал силе Твоје послаће ти Господ са } \\
\text { Сиона }\end{array}$ & $\begin{array}{l}\text { И жезао силе Твоје с висине пошаљи } \\
\text { Господе }\end{array}$ \\
\hline
\end{tabular}

45 У неким преводима „са висина”. 
У молитви за раслабљенога, поново ће тражити помоћ са висина, подигавши своје преподобне руке на висину небесну. Руке се пружају Њему, јер се рука Његова тражи: „Пошаљи руку Твоју са висине, извуци ме и избави ме од вода многих, из руку синова туђинаца.” (Пс, 143, 7).

\section{Глорификација висина наспрам овоземаљског}

„Јер шта ја то имам на небу, и осим Тебе шта хтедох на земљи”, Пс, 72, 25.

Разлог због кога ће Сава, а потом и његов отац Немања напустити законитости земаљског света управо јесте призив ка нечему вишем - призив ка небесима, јер земаљько је замалено ияарство наспрам висина. Већ на почетку Житија, у делу о одласку чудног дечака у Свету Гору, говори се да је Сава, жељом Његовом, предвидео шта је на висинама. Док ће у писму свом оцу глорификовати небеске наспрам земаљских висина ${ }^{46}$ : „Јер земља, ненапојена са вишњих висина распадајући се свагда, вапије ка свом творцу, да јој пошаље рани и позни дажд" 47 . Примећено је да, такође, похвале исказују симболику односа земаљског и небеског. Сава настоји да Немањи укаже „на пролазност овога света и непролазност небеског, који се заслужује подвигом, да га привуче у Свету Гору, где ће се уз њега подвизавати и на тај начин стећи небеско царство, светитељски чин и мироточивост" 48 . Напослетку, обојица ће оставити толику (овоземаљску) висину, од свега земаљског отуђивши се:

„Обојица земаљски анђели, небески људи, небопарни орлови, који су својој светошћу и превеликим уздржавањем узлетели на небеску висину” (2001: 33)

Као што можемо уочити, Доментијанова поетика висина у својој бити јесте тријумф оноземаљског наспрам овоземаљског и свеприсутна је тежња његових јунака да путем небеских лествица достигну Царство Божије.

Уочава се, такође, да мотиви који творе поетику узвишеног, креирају особени концепт хронотопа. Наиме, пут од земље до небеских и наднебеских висина захвата широки спектар темпоралних и просторних категорија. Суштински, кроз поетику висина, укрштају се поетика простора и поетика времена ${ }^{49}$.

Поетика висина, у своје тематске и мотивске оквире, сажима целокупан временски и просторни опсег: овог века - поднебеског света и будућег века - наднебесног света $^{50}$. Такође, у својој основи, рефлектује двојну артикулацију света у сва три модуса: будућност)

1) Историјски („овај век” и „будући век” се супротстављају као садашњост и

2) Космолошки (земаљско и небеско се супротстављају у буквалном смислу речи)

3) Филозофски (супротстављају се један другоме материја и дух, време и вечност, што може, такође, да се означи као земаљско и небеско, али у оквиру метафоре). ${ }^{51}$

46 Доментијан се ту позива на пету књигу Мојсијеву, 11:14 „Тада ћу давати дажд земљи вашој на вријеме, и рани и позни, и сабираћеш жито своје, и вино своје и уље своје”.

47 Доментијан 2001, 78.

48 Јухас 2001, 24.

49 За потребе овог рада, поменутог проблема дотакли смо се концизно. Верујемо да отворено питање носи већи истраживачки потенцијал.

50 Види Аверинцев 1982, 122.

51 Подела према Аверинцев 1982, 125. 


\section{4. Закључак}

Интертекстуалност, иако овим појмом дефинисана тек у 20. веку, примену својих најзначајнијих поставки налази у делима српске средњовековне књижевности. Идеолошки оквири садржани у канонским делима библијске, светоотачке и богослужбене књижевности представљали су главни литерарни узор на који су се средњовековни писци угледали. Успостављајући комуникацију са литерарном традицијом, средњовековни аутор тежи преузимању идеја, али и конкретних исказа, те се као најчешће врсте интертекста јављају цитати, парафразе, паралеле и алузије.

Јеромонах Доментијан средњовековној књижевности својим делима пружио је особени допринос. Житије Светог Саве својим богатством симбола и међутекстовних релација, представља прави изазов у изучавањима и покашајима дешифровања извора интертекста. У ризници мотива садржаних у поменутом Житију, за потребе извршеног истраживања, усредсредили смо се на оне који творе поетику висина. Дакле, мотиви узвишеног творе поетику висина у чијој суштини јесу тежња ка достизању Царства небеског и обожење. Посматрајући поетику висина у интертекстуалном кључу, уочава се да основни извор интертекста јесу Псалми Давидови, али су присутни и утицаји других књига Светог писма (пета књига Мојсијева, Јеванђеље по Луки). Особени концепт хронотопа, назире се у настојању да се кроз поетику висина укрштају поетика времена и поетика простора.

Напослетку, овај рад представља само иницијално истраживање, као и потенцијални увод за неку будућу студију о поетици висина.

\section{Извори}

Доментијан (2001): Житије Светог Саве. Београд: Српска књижевна задруга.

Нови завјет. Псалтир. Молитвеник. Београд: Издавачки фонд Српске православне цркве Архиепископије беорадско-карловачке, 2009.

\section{Литература}

Анђелковић, Маја (2019): „Савино Житије Светог Симеона и интертекстуалност”, у: Црквене студије, број 16. Ниш: Центар за црквене студије.

Анђелковић, М. (2020): „Интертекстуалне везе Савиног Житија Светог Симеона и I и II Хиландарске повеље”, Осам векова Српске Православне Цркве I-II, књ. II, Београд: Свети Архијерејски Синод Српске Православне Цркве, Православно-богословски факултет.

Аверинцев, Сергејевич Сергеј (1982): Поетика рановизантисјке књижевности. Београд: Српска књижевна задруга.

Бахтин, Михаил (1995): Поводом естетике речи, превела Злата Коцић. Београд.

Богдановић, Димитрије (1991): Историја старе српске књижевности. Београд: Српска књижевна задруга.

Бојовић, Драгиша (2009): „Понављање патристичких цитата у српској црквеној књижевности”, у: Philologia Mediana, год. 1, бр. 1. Ниш: Филозофски факултет.

Бојовић, Драгиша (2004): „Доментијанове позајмице о љубави”, у: Прилози за књижевност, језик, историју и фолклор, књ. LXX, 139-142.

Бојовић, Драгиша (2015): „Истраживања српске рецепције светоотачке књижевности”, у: Црквене студије, број 12. Ниш: Центар за црквене студије. 
Бојовић, Драгиша (2009): „Доментијанова теологија љубави”, у: Трпеза премудрости, Београд: Рашка школа, Ниш: Центар за црквене студије, 85-107.

Бојовић, Драгиша (2019): Српска књижевност и свето предање. Београд: Завод за уџбенике.

Берђајев, Николај (2001): Смисао историје. Београд: Дерета.

Гардзанити Марчелло. Библейские цитать в церковнославянской книжности.http://odrl.pushkinskijdom.ru/LinkClick.aspx?fileticket=8Q1QIHAhTEA\%3D\&ta bid $=5951$

Дојчиновић, Данијел (2016): Написи из теорије и историје старе српске књижевности. Источно Ново Сарајево: Завод за уџбенике и наставна средства.

Живковић, Душан (2010): „Појам интертекстуалности”, у: Наслеђе 16. Крагујевац: Филолошко-уметнички факултет.

Јухас Георгиевска, Љиљана (2001): „Књижевно дело јеромонаха Доментијана”, y: Житије Светога Саве. Београд: Српска књижевна задруга.

Јуван, Марко (2013): Интертекстуалност. Нови Сад: Академска књига. du Seuil.

Кристева, Јулија (1969): Semeiotike Recherche pour une Semanalyse. Paris: Editions

Костић Тмушић, Александра (2017): Поетски елементи у српској хагиографској кьижевности, Филозофски факултет у Приштини, Међународни центар за православне студије, Ниш, Косовска Митровица.

Константиновић, Зоран (2002): Интертекстуална компаратистика, Београд: Народна књига, Алфа.

Лахман, Ренате (2015): „Интертекстуалност: покушаји дефинисања појма”, у: Поља, бр. 458, стр. 103-111.

Лазић, Милорад (1997): Естетика Доментијанових житија, Подгорица.

Лома, Миодраг (2012): „Рајско време и историјско невреме. Схатање времена у Библији", у: Аспекти времена у књижевности, ур. др Лидија Делић. Београд: Институт за књижевност и уметност.

Младеновић, Горан (2012): Давидови псалми као израз поетско-религиозне егзистениије аутора, Београд: Филолошки факултет https://nardus.mpn.gov.rs/bitstream/ handle/123456789/4017/Disertacija.pdf?sequence=4\&isAllowed=y

Наумов, Александар (2009): Старо и ново, Ниш: Центар за црквене студије.

Немат, Сара (2020): „Интертекстуалност у Доментијановом Житију Светог Саве", Филолог 21, Бања Лука: Филолошки факултет.

Пикио, Рикардо (1993): „Функцията на библейските тематички ключове в литературния код на православното славянство", Православното славянство и старобългарската културна традиция, 385-435.

Стојановић, М. „Интертекстуалност и цитатност као књижевни поступци, у: Книжевне теорије 20. века, Београд: Институт за књижевност и уметност, 2004.

Трифуновић, Ђорђе (1972): „Доментијан песник светлости”, Стара књижевност, Београд: Нолит. Хрватске.

Толић Ораић, Дубравка (1990): Теорија циттатности, Загреб: Графички завод

Хафнер, Станислав (2001): „Доментијан и Слово о закону и благодети митрополита кијевског Илариона”, у: Српски средњи век, прев. Јованка Калић, Слободан Грубачић, Београд: ЗУНС, Вукова задужбина, Нови Сад: МС.

Шеатовић Димитријвић, Светлана (2004): Традиција и иноващчија, Интертекстуалност у песништву Иван В. Лалића. Београд: Филип Вишњић.

Шпадијер, Ирена (1997): „Библијска мјеста у Житију Светог Петра Коришког Теодорсија Хиландарца", Српска књижевност и Свето писмо, Београд: Међународни славистички центар. 


\section{Teodora D. Bojović}

\section{DOMENTIAN'S POETICS OF THE HEIGHTS IN AN INTERTEXTUAL KEY}

The paper first provides a genesis of present-day positions on intertextuality in order to facilitate the recognition of basic traits of this theory in the works of old Serbian literature. Since the use of authoritative texts as role models, intermingling of texts and interweaving of discourses are some of the most important traits of old literature, intertextuality as a framework is broadly used in the appreciation of such pieces. The motives of the exalted in Domentian's poetic narratives from The Life of St. Sava engender a poetics of the heights. This poetics, in turn, relies on the phenomena such as reaching the Kingdom of Heaven, deification and the revelation of the Logos. In an intertextual key, the aforementioned motives are analyzed through their varying thematic aspects, whereby the basic sources of the intertext are identified. Ultimately, it is concluded that motives comprising the poetics of the heights create a specific form of chronotype, where the poetics of space and the poetics of time intersect. 